NBER WORKING PAPER SERIES

BENEFITS OF CONTROL, MANAGERIAL

OWNERSHIP, AND THE STOCK

RETURNS OF ACQUIRING FIRMS

\author{
R. Glenn Hubbard \\ Darius Palia
}

Working Paper No. 5079

\author{
NATIONAL BUREAU OF ECONOMIC RESEARCH \\ 1050 Massachusetts Avenue \\ Cambridge, MA 02138 \\ April 1995
}

We thank Bernie Black, Bent Christensen, Jordi Gali, Vic Goldberg, Frank Lichtenberg, Jim Poterba, N.R. Prabhala, Mark Roe, and Mike Weisbach for helpful comments and Walter Bailey, Carlene Palia, and Meng Tan for their research assistance. Hubbard acknowledges support from the Federal Reserve Bank of New York and the Center for the Study of the Economy and the State of the University of Chicago, and Palia acknowledges support from the Faculty Research Fund of the Graduate School of Business of Columbia University. All errors remain our responsibility. This paper is part of NBER's research program in Corporate Finance. Any opinions expressed are those of the authors and not those of the National Bureau of Economic Research.

(C) 1995 by R. Glenn Hubbard and Darius Palia. All rights reserved. Short sections of text, not to exceed two paragraphs, may be quoted without explicit permission provided that full credit, including $\odot$ notice, is given to the source. 


\title{
BENEFITS OF CONTROL, MANAGERIAL OWNERSHIP, AND THE STOCK RETURNS OF ACQUIRING FIRMS
}

\begin{abstract}
This paper examines the effect of the benefits of corporate control to managers on the relationship between managerial ownership and the stock returns of acquiring firms in corporate control transactions. At low levels of managerial ownership, agency costs of equity (such as perquisite consumption) reduce the returns earned by acquirers. As the managerial stake in the acquiring firm increases, the interests of managers are more closely aligned with those of shareholders, reducing the acquisition premium. At sufficiently high levels of managerial ownership, managers value a reduction in the risk of their nondiversified financial portfolio. However, managers enjoy nonassignable private benefits of control at high levels of ownership which they are not willing to lose by selling their stake in the financial markets. These benefits of control are increasing in the managerial ownership stake and can lead to managers "overpaying" even when they own a substantial fraction of the firm. Examining mergers that occurred during 1985 to 1991 , we find evidence of such a nonmonotonic relationship between the stock returns earned by acquirers and their managerial ownership level. Further, we find that acquiring firms with high levels of managerial ownership tend to diversify more than acquiring firms with low levels of managerial ownership.
\end{abstract}

R. Glenn Hubbard

Graduate School of Business

Columbia University

609 Uris Hall

New York, NY 10027

and NBER
Darius Palia

Graduate School of Business

Columbia University

414 Uris Hall

New York, NY 10027 


\section{Introduction}

Beginning with Berle and Means (1932), the issue of whether managers maximize shareholder wealth has generated considerable debate. Rather than maximizing shareholder wealth, managers may maximize their own utility either through the consumption of perquisites (as in Jensen and Meckling, 1976) or through the selection of less risky investment projects (as in Amihud and Lev, 1981). Managerial ownership acts as an incentive for managers to align their interests with the shareholder's interests. Accordingly, under these theories more ownership in the hands of managers leads to greater value. The monotonicity of this relationship has been recently questioned. Mørck, Shleifer, and Vishny (1988) find that value is also adversely affected at high levels of managerial ownership, as managers are entrenched and free from the discipline of their shareholders. Consequently, value first increases and then decreases with increases in the managerial ownership stake. This nonmonotonic relationship has been confirmed by McConnell and Servaes (1990) and Hermalin and Weisbach (1991). ${ }^{1}$

These papers have examined the relationship between managerial ownership and value (as captured by Tobin's $q$ ). We examine one aspect of this relationship, specifically, do manager's who own less in the firm tend to "overpay" when they acquire a target firm? Accordingly, this paper focuses on the relationship between the managerial ownership stake in acquirer firms and the size of the premiums that these managers offer in an acquisition. As Shleifer and Vishny (1988, pp. 13-15) state in their review of the literature:

"Ironically, the literature that focussed on takeovers as devices to eliminate non-value-maximizing behavior has almost forgotten the bidders, despite the fact that acquisitions may be the most important decisions about the allocation of corporate wealth that managers make. Acquisitions, especially friendly ones, may provide managers their greatest opportunity for expressing their nonvalue-maximizing preferences. ... For them, the purchase of other companies at inflated prices may be the grandest deviation from value-maximization."

Therefore the relationship between the premiums paid and the managerial ownership stake is an important (non-)value-maximizing activity to be examined.

Under the traditional aligned-interest hypothesis, managers indulge in any non-valuemaximizing transaction such as excessive consumption of perquisites or sub-optimal risk

\footnotetext{
${ }^{1}$ To assess the effects of managerial share ownership on shareholder value (measured by Tobin's q), Mørck, Shleifer, and Vishny estimated a piecewise-linear specification in ownership levels (using cross-sectional data). They find that Tobin's $q$ increases in managerial stakes over a low range of managerial ownership, with a negative relationship thereafter. McConnell and Servaes provide additional evidence on the empirical relationship between managerial ownership and firm value using 1976 and 1986 data. They find an inverted U-shaped relationship, which is quadratic in managerial ownership. Hermalin and Weisbach address the possibility of simultaneity between managerial ownership and Tobin's $q$ using panel data. They also find that shareholder value increases with managerial stakes at low levels of ownership, while decreasing at large ownership levels; they postulate that, over certain ranges, corporate performance may decline with ownership, "possibly because the increasing relationship from disciplinary devices more than offsets the increased alignment of interests." (pp. 112)
} 
taking activities when the managers do not own a significant ownership stake in the firm. As the managerial ownership in the firm increases, managers interests become more aligned with those of the shareholders of the firm, resulting in the managers consuming lower level of perquisites, and reporting larger earnings to shareholders. Thus under the aligned-interest hypothesis, a negative relationship is proposed between the percentage of stock owned by managers and the bid premium offered. Evidence in support of this hypothesis is found in Lewellen, Loderer, and Rosenfeld (1985), who examine 266 mergers during the period 1963 to 1981. They find that firms that had lower managerial ownership levels earned negative abnormal returns. ${ }^{2}$

Under the above hypothesis, it would be optimal for the shareholders of the firm to increase the managers' ownership stake. This would result in a higher value of the firm due to an increasing convergence between manager and shareholder interests. However, at high levels of managerial ownership, the managers begin to hold a large undiversified financial portfolio in the firm. Will the managers use the financial markets to reduce the risk of their financial portfolio? Are there certain benefits of control that the managers would have to surrender if they sold their ownership stake in the firm? These are some of the questions that the aligned interest hypothesis does not address.

In response, we propose the diversification-control hypothesis. This hypothesis addresses on the impact of the private benefits of control to the managers on the bid premium. Under the diversification-control hypothesis, firms in which managers do not initially possess a significant ownership stake indulge in non-value-maximizing activities. With increases in managerial stockholdings the interests of the managers become more compatible with shareholder interests, resulting in a negative relationship between the bid premium and the managerial equity stake. However at sufficiently high levels of managerial ownership, the managers (who could now be classified as significant shareholders), begin to hold a large nondiversified financial portfolio in the firm. The managers do not sell their stake in financial markets as they do want to retain the benefits of controlling the firm. If managers value control, their incentive to diversify their nondiversified financial portfolio increases as their managerial stake increases. Further, these benefits of control are increasing in their managerial ownership stake resulting in the managers offering a higher bid premium even when they own a significant part of the firm. Thus, under the diversification-control hypothesis, we propose a negative

\footnotetext{
${ }^{2}$ If stock prices reflect available information, then offering high bid premiums should cause the acquirer's abnormal returns to fall. Therefore, throughout this paper, we will use bid premiums and abnormal returns interchangeably (with the reminder that bid premiums and abnormal returns are negatively related to each other).
} 
relationship between the bid premium and the managerial ownership stake at low values of managerial ownership, and a positive relationship at high levels of managerial ownership.

Incomplete contracting is the key element in our approach. First, we model perquisite consumption by the manager as private action and hence noncontractable. This is similar in spirit to perquisite consumption in Jensen and Meckling (1976) or unobservable choice of effort in Holmstrom (1979). In addition, at high ownership stakes, managers also enjoy private benefits of control. These benefits of control are available only to the party in control and are contractually nonassignable and hence noncontractable. Here, however, more managerial ownership causes managers to have more private benefits of control. We treat perquisite consumption and benefits of control distinctly from each other. Although these have common aspects, one can think of benefits of control as the residual rights of ownership and perquisite consumption as the unobservable non-value-maximizing activity ${ }^{3}$ in which managers indulge. More important, managers do not need ownership to consume perquisites but earn the private benefits of control $^{4}$ through the acquisition of an ownership stake.

Accordingly, we provide an overview of the model and derive its main testable implication, namely, the nonmonotonic relationship between the bid premium and the acquirer's managerial ownership stake. In the diversification-control hypothesis, managers of acquiring firms overpay when their ownership stake is low (attributable to unobservable perquisite consumption) and when their ownership stake is high (due their private benefits of control). We examine empirically this relationship between the bid premium and the acquirer's managerial ownership level. We use the fact that bid premiums (the price paid for the target company) are inversely related to the returns earned by the acquirer. Consequently, empirical support for the diversification-control hypothesis is provided if the abnormal returns first increase and then decrease as the acquirer's managerial ownership level increases. We examine 172 mergers during the years 1985 to 1991, and find strong evidence in support of this relationship.

In the following section, we present a simple principal-agent model that is intended to capture parsimoniously this nonmonotonic relationship between the stock returns of

\footnotetext{
${ }^{3}$ See Jensen and Meckling (1976) and Holmstrom (1979).

${ }^{4}$ One might interpret the benefits of control (at high levels of managerial ownership) as the degree of control that the manager has over the board. Companies with high managerial ownership levels tend to have a high number of insiders on the board and CEOs with longer tenure (see, Hermalin and Weisbach, 1988); and consequently enjoy high benefits of control.
} 
acquiring firms and their managerial ownership levels. Accordingly, a few caveats about our model are necessary. First, we do not examine why mergers take place, we only model the relationship between the managerial ownership levels and the stock returns of acquiring firms. Hence, in our model mergers take place at both high and low levels of managerial ownership. Second, we assume that the acquisition is financed entirely through internal funds. We do not examine the effect of the capital structure decision on the stock returns of acquirers, given that Jensen (1986), Harris and Raviv (1988), and Grossman and Hart (1988), have shown that debt constrains managerial control. ${ }^{5}$ Third, we do not model all aspects of the portfolio decision of managers. For example, managers might diversify their financial risk in the firm by using other instruments available in the financial markets. However, if they sell their stake in the firm they will lose the benefits of control. Consequently, we have a simple portfolio decision of a wealth-constrained manager, rather than explicitly including the relationship his stake in the firm has to other securities that he or she holds. These restrictions limit the generality of our model. However, they allow us to focus explicitly on the relationship between the stock returns of acquiring firms and their managerial ownership levels in a simple and empirically testable fashion.

Many studies have addressed the value of the right to control a firm. ${ }^{6}$ These benefits of control are available to the party in control. In modeling contests for control, for example, both Grossman and Hart (1988) and Harris and Raviv (1988) use the concept that there are benefits of control that are valued separately from a firm's cash flows. The presence of benefits of control causes managers to maximize both their private control benefits and their cash flow benefits. Are there any benefits of control that are separate from the firm's cash flows? Harris and Raviv (pp. 61) argue that the market value of the firm reflects only the firms cash flows as the "competition among passive investors will drive the market price to the present value of the cash flows net of the benefits of control." The incumbent management team receives the benefits of control, which is terminated in the event of a takeover or bankruptcy.

Empirical evidence suggests that there are benefits of control which allow different valuation of stocks with different voting rights. For example, a study by the Office of the

\footnotetext{
${ }^{5}$ However, Mørck, Shleifer, and Vishny (1988), and McConnell and Servaes (1990) have empirically found an increasing and then decreasing relationship between shareholder value (Tobin's q) and managerial ownership, while controlling for debt as a separate independent variable. Therefore, debt does not affect the nonmonotonic relationship between shareholder value and managerial ownership. Consequently, we do not model the choice of debt or external equity in the financing of the acquisition.

${ }^{6}$ For examples of such an assumption see Grossman and Hart (1988), Harris and Raviv (1988), and Diamond (1990)
} 
Chief Economist, SEC (1987), examines 26 OTC and AMEX firms having dual-class stock and finds that low-vote common stock trades at a discount of four percent to five percent. Lease, McConnell, and Mikkelson (1983) examine 30 firms having dual-class stock and show that voting stock trades on average at a one percent to seven percent premium. DeAngelo and DeAngelo (1985) examine 45 firms with dual-class stock and find that management and family insiders control 57 percent of the voting rights and only 24 percent of the common stock cash flows. They also find that dual-class structures often confer substantial voting powers on incumbent management. Barclay and Holderness (1989) examine 63 negotiated block trades and find premiums averaging 19.7 percent over the post-announcement exchange quoted price. These private benefits of control increase at a increasing rate with fractional ownership and the total dollar value of benefits increase with firm size. These studies suggest that the right to control a firm is valuable and often rests with the current management of the firm.

Section 2 provides a description of the model. In Section 3 we describe the data used and the results of an event study to explicitly test the (nonmonotonic) relationship between managerial ownership and the acquirer's abnormal returns. Our conclusions and possible directions for future research are discussed in Section 4.

\section{Model}

The underlying framework is a single-period principal-agent relationship between a firm's shareholders and its managers. Both shareholders and managers maximize their expected utilities of end-of-period wealth, $\tilde{W}: E V(\tilde{W})$ and $E U(\tilde{W})$, respectively. We assume all shareholders are identical and are risk-neutral. ${ }^{7}$ For simplicity, we assume a single manager $^{8}$ who holds the fraction $\alpha$ of the total outstanding shares in the firm. Let $p$ be the stock price of the firm. The firm's cash flow ${ }^{9}$ is represented by $A(\tilde{\theta}-h)$ $f K(\alpha)-W$, where $A$ is the size of assets of the firm, $\tilde{\theta}$ the cash flow per dollar of assets (where $\tilde{\theta} \sim N\left(\mu_{1}, \sigma_{1}^{2}\right)$ ), $h$ is the actual monetary value of non-value-maximizing activities such as perquisites, $f$ is a positive fraction, $K(\alpha)$ the benefits of control that accrue to

\footnotetext{
${ }^{7}$ It is generally assumed that shareholders are risk neutral, as they can diversify their financial risk by holding a number of securities in the financial markets. For example, see Grossman and Hart (1981). Given that shareholders are identical, their expected utility can be considered as the expected utility of an aggregate shareholder. Hence we use shareholder and shareholders interchangeably. We also implicitly assume that shareholders are diffuse, individually small and passive as in Harris and Raviv (1988), Stulz (1988), and Grossman and Hart (1988).

${ }^{8}$ We can think of the single manager as an aggregate manager; see Wilson (1968) for methods of aggregation when agents have negative exponential utility functions.

${ }^{9}$ In order to focus on non-synergistic motives for mergers we implicitly have assumed constant returns to scale.
} 
managers as a function the managerial ownership stake $\alpha$, and $W$ represents the fixed wages paid to the managers. The stock price is the current valuation of the observed cash flows $A(\tilde{\theta}-h)-f K(\alpha)-W$. Let $g(h)$ be the value the manager obtains from non-valuemaximizing activities or perquisites. We assume that $g$ is concave in $h$ in order to capture the manager's diminishing marginal value for perquisites. $M_{m}$ is the fraction of the market portfolio of stocks held by managers. $M_{m}^{\circ}$ is the fraction of the market portfolio of stocks held by shareholders. The price of the market portfolio of stocks is given by $\tilde{Z}$ where $\tilde{Z}$ is distributed normal with mean $\mu_{m}$ and standard deviation $\sigma_{m}^{2}$. The manager possesses a CARA utility function. Let $\alpha^{*}$ be the optimal quantity of shares (from a shareholders perspective) that the manager holds in his firm. The manager's optimal choice of perquisites for an optimal level of $\alpha^{*}$ is represented by $h^{*}\left(\alpha^{*}\right)$.

Control and $\boldsymbol{\alpha}^{*}$. A major factor which drives the managerial incentives in our framework is the private benefits of control. As in Harris and Raviv (1988), we start with the premise that the right to control a large corporation is valuable. These benefits of control are available to the party in control and cannot be contracted away to other agents including securityholders (see also Grossman and Hart, 1982,1988). Examples of such private benefits include discretion over the choice of investment projects, effective control over the appointment of members of the board of directors (for example, can appoint more insiders who vote on issues similar to management), extension of the tenure of the $\mathrm{CEO}$, returns to firm-specific investments to human capital, synergy with other projects run by the management, reputational effects arising from successfully managing a large firm, etc. We will denote such private benefits as $K(\alpha)$, where $K(\alpha)$ captures the monetary value of the private benefits of control to a manager who owns a fraction $\alpha$ of the firm. We also assume that: $K(\alpha)$ is non-decreasing in $\alpha$, i.e., the value of control does not diminish as $\alpha$ increases and is convex in $\alpha$; and, below some minimum level of $\alpha$ there are no benefits of control. ${ }^{10}$ Hence, we require $K(\alpha)$ to satisfy the following condition:

$$
\begin{aligned}
K(\alpha) & =0 & & \text { for } \alpha \leq \alpha_{1} \\
& =\alpha^{3} k & & \text { for } \alpha>\alpha_{1}
\end{aligned}
$$

for some $\alpha_{1}>0, k>0$.

The shareholder chooses the optimal $\alpha^{*}$ as generated by the following program.

\footnotetext{
${ }^{10}$ We have assumed convexity for to capture the idea that the value of the benefits of control to managers is "intoxicating" (in that the marginal value of control increases at an increasing rate at high values of $\alpha$ ).
} 


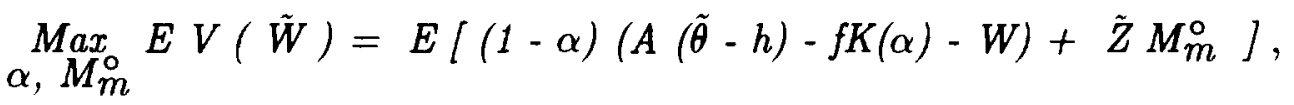

subject to

$E U(\tilde{W})=E\left[-\exp \left(-r\left[\alpha(A(\tilde{\theta}-h)-f K(\alpha)-W)+g(h)+W+\tilde{Z} M_{m}+K(\alpha)\right]\right)\right] \geq \bar{U}$,

and

$$
h \epsilon \underset{h^{\prime}}{\operatorname{argmax}} E U\left[\left(\alpha, h^{\prime}\right)\right] .
$$

Constraint (2) is the participation constraint, which guarantees the agent a minimum expected utility (achieved via a market or negotiation process). Constraint (3) is the incentive-compatibility constraint which indicates that the shareholders cannot directly observe the level of $h^{*}$ consumed by managers. ${ }^{11}$ Hence, we solve a sequential program with managers initially solving their optimal perquisite consumption level, within the boundaries of the general compensation plan derived by shareholders. ${ }^{12}$

The manager chooses the optimal level of perquisites $h^{*}$ by maximizing the following objective function:

$$
\begin{aligned}
& \underset{h}{\operatorname{Max}} E U(\tilde{W})=E[-\exp (-r / \alpha(A(\tilde{\theta}-h)-f K(\alpha)-W)+ \\
& \left.\left.\left.g(h)+W+\tilde{Z} M_{m}+K(\alpha)\right]\right)\right] .
\end{aligned}
$$

For simplicity, we assume that the only $\alpha$ that manager owns is given to him or her by the shareholders. Therefore he does not buy any shares from the financial markets. ${ }^{13}$ For concreteness, we study a specific functional form for managerial perquisite consumption. Let $s \sqrt{h}$ be the concave utility function for perquisites. ${ }^{14}$ The objective in (4) is equivalent

\footnotetext{
${ }^{11}$ By assuming $f$ to be a positive fraction less than one, we allow the manager to get higher benefits of control than just the cash losses that accrue to the shareholder due to the manager's control.

${ }^{12}$ As we are using standard moral hazard arguments, it is obvious that the optimal sharing rule obtained from solving the above sequential program will not be Pareto optimal.

${ }^{13}$ The results do not change in any substantial manner if we allow the managers to also vary their $\alpha$ and $M_{m}$. Equation (4) would have to be maximized with respect to the amount of shares traded by the manager $\phi$ and $M_{m}$ subject to a budget constraint of the form $\dot{Z} M_{m}+p(\alpha+\phi)(\alpha+\phi) N \leq \dot{Z} \bar{M}_{m}+p(\alpha) \alpha N$. $\bar{M}_{m}$ is the initial managerial endowment of (the quantity of) market portfolio shares and $\alpha$ the amount of shares given to the manager by the shareholders.
} 
to:

$$
\begin{aligned}
& \underset{h}{\operatorname{Max}} E\left[\alpha(A(\tilde{\theta}-h)-f k-W)+s \sqrt{h}+W+\tilde{Z} M_{m}+\alpha^{3} k\right] \\
& -\frac{r}{\mathscr{Q}} \operatorname{var}\left[\alpha(A(\tilde{\theta}-h)-f k-W)+s \sqrt{h}+W+\tilde{Z} M_{m}+\alpha^{3} k\right]
\end{aligned}
$$

The optimal perquisites level $h^{*}(\alpha)$ is obtained by maximizing (5) and must satisfy the necessary condition: ${ }^{15}$

$$
\begin{aligned}
0 & =\frac{\partial}{\partial h}\left\{E\left[\alpha\left(A\left(\tilde{\theta}-h^{*}\right)-f k-W\right)+s \sqrt{h^{*}}+W+\tilde{Z} M_{m}+\alpha^{3} k\right]\right. \\
& \left.-\frac{r}{2} \operatorname{var}\left[\alpha\left(A\left(\tilde{\theta}-h^{*}\right)-f k-W\right)+s \sqrt{h^{*}}+W+\tilde{Z} M_{m}+\alpha^{3} k\right]\right\}
\end{aligned}
$$

Thus, at the optimum, we find:

$$
h^{*}(\alpha)=\frac{s^{2}}{4 A^{2} \alpha^{2}}
$$

We observe from (7) that $\frac{\partial h^{*}(\alpha)}{\partial \alpha}=-\frac{2 s^{2}}{4 A^{2} \alpha^{3}}<0$, indicating that, as managerial ownership increases, the manager spends less on perquisite consumption. Although this result is well-known (see, e.g., Jensen and Meckling, 1976), we use it as a starting point and and highlight it for ease of reference below:

Proposition 1. For low levels of managerial ownership, i.e., $\alpha^{*} \leq \alpha_{1}$, the amount of perquisites consumed by managers is decreasing in managerial ownership stake.

For sufficiently large values of $k$, the value of control to the managers is high. Hence, acquirer firms with a managerial ownership stake greater than $\alpha_{1}$ will not diversify the firm's cash flow through the financial markets. ${ }^{16}$ Let the firm have $d(A(\tilde{\theta}-h)-f k-W)$ funds which it can use either to expand its own operations internally or to acquire another

\footnotetext{
${ }^{14} \mathrm{As} s$ is an arbitrary parameter we may want to choose the gains from perquisite consumption to increase with the size of the bank. Hence we would make $s$ directly proportional to the asset size $A$.

${ }^{15}$ Given that we have a constant returns to scale technology, the optimal amount of perquisites $h^{*}$ consumed by the manager is independent of $\mu_{1}$.

${ }^{16}$ As noted earlier, we have assumed that the acquirer finances the entire acquisition through internal funds, eliminating the need for debt. This allows us to focus our discussion in a simple framework on $\alpha$ and the bid premium.
} 
firm; the remaining cash flows are $(1-d)(A(\tilde{\theta}-h)-f k-W)$. If the firm expands internally, the profits would increase by $d(A(\tilde{\theta}-h)-f k-W)$. Alternatively, the firm can acquire another firm with gross profits per dollar of assets of $\tilde{\gamma}$, where $\gamma \sim N\left(\mu_{2}, \sigma_{2}^{2}\right) .{ }^{17}$ To focus on the non-synergistic motives for mergers, we assume $\mu_{1}>\mu_{2}$, and $\sigma_{1}^{2}=\sigma_{2}^{2}=\sigma^{2}$. Let $\alpha^{*}>\alpha_{1}$ be the total intensity of perquisite consumption and $\hat{h}$ be the new level of perquisite consumption by the managers after the acquisition (and is equal to $\frac{t^{2}}{4 A^{2} \alpha^{2}}$ ). After the acquisition, the wealth of the managers (excluding his returns from the market portfolio) is:

$$
\alpha^{*}\left[(1-d) A \tilde{\theta}+d A \tilde{\gamma}-A \hat{h}-f K\left(\alpha^{*}\right)-W\right]+t \sqrt{\hat{h}}+W+K\left(\alpha^{*}\right)
$$

We restrict the correlation between $\theta$ and $\gamma$ to be less than unity so that the reservation bid $b$ that the acquiring management is willing to pay will be greater than zero. Hence the firm pays $(d A \tilde{\theta}+b)$ for the target firm's cash flow of $d A \tilde{\gamma}$. Assuming competition in the acquisition market, the reservation bid $b$ will satisfy:

$$
E U\left[\tilde{W}^{N}\right]=E U\left[\tilde{W}^{T}-\alpha^{*} b\right]
$$

where $\tilde{W}^{N}$ is the (random) wealth if no acquisition occurs and $\tilde{W}^{T}$ is the (random) wealth if an acquisition does occur.

We define $\left(\alpha^{*}\right)^{3} k_{1}$ and $\left(\alpha^{*}\right)^{3} k_{2}$ as the monetary value of control to the managers before and after the acquisition. Given that the managers value control, that is, the acquisition allows them to have high private benefits of control, we allow $k_{2}>k_{1}$. We can rewrite (9) as:

$$
\begin{aligned}
& E U\left[\alpha^{*}\left(A\left(\tilde{\theta}-h^{*}\right)-f k_{1}-W\right)+s \sqrt{h^{*}}+W+\tilde{Z} M_{m}^{*}+\left(\alpha^{*}\right)^{3} k_{1}\right]= \\
& E U\left[\alpha^{*}\left((1-d)\left(A(\tilde{\theta}-\hat{h})-f k_{2}-W\right)+d\left(A(\tilde{\gamma}-\hat{h})-f k_{2}-W\right)\right)+\right. \\
& \left.\quad t \sqrt{\hat{h}}+W+\tilde{Z} M_{m}^{*}+\left(\alpha^{*}\right)^{3} k_{2}-\alpha^{*} b\right] .
\end{aligned}
$$

Note that the assumption $s<t$ implies that the marginal value of each dollar spent on

\footnotetext{
${ }^{17}$ We do not model why mergers take place, but rather the appropriate relationship between the returns earned by acquirers and their managerial ownership levels. Accordingly, mergers take place at both high and low managerial ownership levels.
} 
perquisites is higher after the merger. ${ }^{18}$ Equating certainty-equivalents in (10) yields:

$$
\begin{aligned}
& \alpha^{*}\left(A\left(\mu_{1}-h^{*}\right)-f k_{1}-W\right)+s \sqrt{h^{*}}+W+\mu_{m} M_{m}^{*}+\left(\alpha^{*}\right)^{3} k_{1} \\
& -\frac{r}{2}\left\{\left(\alpha^{*}\right)^{2} A^{2} \sigma^{2}+\left(M_{m}^{*}\right)^{2} \sigma_{m}^{2}+2 \alpha^{*} A M_{m}^{*} \operatorname{cov}(\theta, m)\right\}= \\
& \alpha^{*}\left((1-d)\left(A\left(\mu_{1}-\hat{h}\right)-f k_{2}-W\right)+d\left(A\left(\mu_{2}-\hat{h}\right)-f k_{2}-W\right)\right)+t \sqrt{\hat{h}}+W+\mu_{m} M_{m}^{*} \\
& +\left(\alpha^{*}\right)^{3} k_{2}-\alpha^{*} b-\frac{r}{2}\left\{\left(\alpha^{*}\right)^{2}(1-d) A^{2} \sigma^{2}+\left(\sigma^{*}\right)^{2} d^{2} A^{2} \sigma^{2}+\left(M_{m}^{*}\right)^{2} \sigma_{m}^{2}+\right. \\
& \left.2\left(\alpha^{*}\right)^{2} A^{2} d(1-d) \operatorname{cov}(\theta, \gamma)+2 \alpha^{*} d A M_{m}^{*} \operatorname{cov}(\gamma, m)+2 \alpha^{*}(1-d) A M_{m}^{*} \operatorname{cov}(\theta, m)\right\} .
\end{aligned}
$$

Solving (11) for $b$ we get:

$$
\begin{aligned}
b & =d A\left(\mu_{2}-\mu_{1}\right)-\frac{\left(s^{2}-t^{2}\right)}{4\left(\alpha^{*}\right)^{2} A}+\left(\alpha^{2}-f\right)\left(k_{2}-k_{1}\right) \\
& -\frac{r}{2}\left\{\alpha^{*} A^{2}\left[\delta-\sigma^{2}\right]+2 A M_{m}^{*} d[\operatorname{cov}(\gamma, m)-\operatorname{cov}(\theta, m)]\right\}
\end{aligned}
$$

where $\delta \equiv(1-d)^{2} \sigma^{2}+d^{2} \sigma^{2}+2 d(1-d) \operatorname{cov}(\theta, \gamma)$. Taking the derivative of the bid $b$ with respect to $\alpha^{*}$ gives:

$$
\frac{\partial b}{\partial \alpha^{*}}=\frac{\left(s^{2}-t^{2}\right)}{2\left(\alpha^{*}\right)^{3} A}+\left[-\frac{r}{2} A^{2}\left[\delta-\sigma^{2}\right]\right]+2 \alpha^{*}\left(k_{2}-k_{1}\right) .
$$

The sign of $\frac{\partial b}{\partial \alpha^{*}}$ is controlled by the terms in (13) which have a natural interpretation. The first term is the reduction in perquisite consumption by managers. We note that it is negative, and its magnitude decreases as $\alpha$ increases. Hence, at low levels of ownership, managers pay a high bid premium in order to consume more perquisites. As the ownership stake increases, the bid premium decreases at a decreasing rate. When there are possible gains to diversification (that is, the correlation between $\theta$ and $\gamma$ is less than unity), the second term is positive but does not fluctuate with $\alpha$. The third term represents the private benefits of control, and is positive (given that the managers value control) and its magnitude increases as $\alpha$ rises. At low levels of $\alpha$, then, the first term in (13) dominates the second and third terms. This results in a negative relationship between the bid

\footnotetext{
${ }^{18}$ That is, the perquisite dollar can be used by the manager on more discretionary alternatives after the merger, making it more valuable.
} 
premium and the managerial ownership stake. At high levels of $\alpha$, the second and third terms dominate the first term in (13), and $\frac{\partial b}{\partial \alpha^{*}}>0$. Hence we find a nonmonotonic relationship between the bid premium and the managerial ownership stake.

Proposition 2. The bid premium is first decreasing in $\alpha$ and then increasing in $\alpha$; $b$ is convex in $\alpha$.

The intuition behind this proposition is clear. At low levels of $\alpha$, the managers are willing to pay a high premium so as to indulge in perquisite consumption. As $\alpha$ increases, the agency costs associated with managers maximizing their own utility decreases. However at sufficiently high levels of managerial ownership, the managers (who now could be classified as significant shareholders) begin to hold a large undiversified financial portfolio in the firm. As the managers value control they are not willing to sell their stake in the financial markets. Given that the private benefits of control increases with their managerial ownership stake, the managers indulge in their benefits of control and pay a high bid premium. Hence under the diversification-control hypothesis, a nonmonotonic convex relationship is proposed as follows. At low values of managerial ownership, we find an negative relationship between the bid premium and the managerial ownership stake and at high levels of managerial ownership a positive relationship is posited.

The comparative statics of $\alpha^{*}$, the optimal ownership fraction of managers with respect to the parameters of the problem yields some additional relationships.

We formalize the shareholders' optimization problem as follows:

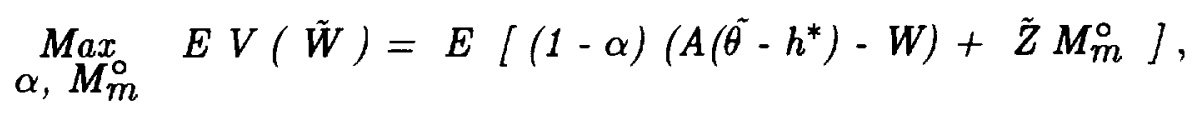

subject to $E\left[-\exp \left(-r\left[\alpha\left(A\left(\theta^{\sim}-h^{*}\right)-W\right)+s \sqrt{h^{*}}+W+\tilde{Z} M_{m}\right]\right)\right] \geq \bar{U}$,

and

$$
h^{*}=\frac{s^{2}}{4 A^{2} \alpha^{2}} \text {. }
$$

Substituting (16) into (14) and (15) and recognizing that (15) would be satisfied as an equality at the optimum, ${ }^{19}$ the comparative statics follow readily. For simplicity, let:

\footnotetext{
${ }^{19}$ We justify using the first-order approach since $h(\alpha)$ is concave and $h^{*}$ is an interior point. (The second-order conditions are therefore satisfied.)
} 


$$
\begin{aligned}
\psi \equiv & \alpha\left[A\left(\mu_{1}-\frac{s^{2}}{4 A^{2} \alpha^{2}}\right)-f k-W\right]+\frac{s^{2}}{2 \alpha A}+W+\mu_{m} M_{m}+\alpha^{3} k \\
& -\frac{r}{2}\left[\alpha^{2} A^{2} \sigma_{1}^{2}+M_{m}^{2} \sigma_{m}^{2}+\mathscr{2} \alpha A M_{m} \operatorname{cov}(\theta, m)\right]
\end{aligned}
$$

For any parameter $x$, then,

$\frac{\partial \alpha^{*}}{\partial x}=-\frac{\psi_{x}}{\psi_{\alpha}}$

$\operatorname{sign} \frac{\partial \alpha^{*}}{\partial x}=-\operatorname{sign} \psi_{x}$

if $\alpha^{*}$ is in such a range such that $\psi_{\alpha}\left(\alpha^{*}\right)>0$.

Using (19) we will develop the comparative statics of $\alpha^{*}$ with respect to firm profitability $\mu$, firm risk $\sigma^{2}$, managers' propensity to consume perquisites $s$, and the rate of increase of private benefits of control, $k$.

Firm profitability and $\alpha^{*}$. If the expected profits of the firm are very high, the shareholders give less stock to the managers. (Since $\psi_{\mu}=\alpha A$, we have $\frac{\partial \alpha}{\partial \mu}<0$ ). The intuition behind the above relationship is clear. As shareholders are risk-neutral, their only concern is maximizing their net wealth. The effect of increasing $\alpha$ has two effects on shareholder wealth. The first effect is that increases in $\alpha$ causes the manager to consume a lower amount of perquisites. The second effect is that the profits of the shareholders decreases with increases in $\alpha$, as the shareholder gives $\alpha\left(A\left(\mu_{1}-h\right)-f k-W\right)$ to the manager. The optimal $\alpha^{*}$ is where the marginal benefits of increasing $\alpha$ is equal to the marginal costs. With higher $\mu_{1}$, the marginal costs to the shareholder increases. Thus the shareholders allocate less of the firm's stock to the managers when the expected profits of the firm is high.

Firm risk and $\alpha^{*}$. As the risk of the firm increases, the managerial ownership stake in the firm increases (since sign $\frac{\partial \alpha^{*}}{\partial \sigma^{2}}=\operatorname{sign}\left[\frac{r}{2} \alpha^{2} A^{2}\right]$, which is positive). With increases in firm risk, managers who are risk-averse find their utility decreasing. This results in managers increasing their utility by indulging in the riskless activity of perquisite consumption. Hence, shareholders award the managers a higher ownership stake to prevent excessive perquisite consumption. Therefore, managers have to balance their non-value-maximizing activity of perquisite consumption against their value-maximizing activity of shareholder 
optimal (higher) risk-taking activities. Note that this result is consistent with the empirical results found by Saunders, Strock, and Travlos (1990), who examine a sample of banks and find a positive correlation between risk and the managerial ownership stake. $^{20}$

Managerial intensity of perquisite consumption and $\alpha^{*}$. As the managerial intensity of perquisite consumption or the manager's valuation of perquisites (namely, $s$ ) increases, the optimal managerial ownership increases (since sign $\frac{\partial \alpha^{*}}{\partial s}=-\operatorname{sign} \frac{s}{2 \alpha A}<0$ ). As the manager values perquisites more, perquisites become an attractive way of providing him with his reservation utility. Hence, lowering $\alpha^{*}$ leads the manager to increase perquisite consumption, which is consistent with optimal managerial ownership.

Private benefits of control and $\alpha^{*}$. As the responsiveness $(k)$ of managerial private benefits of control to $\alpha^{*}$ (for $\alpha^{*} \geq \alpha_{1}$ ) increases, the effect on the optimal managerial ownership level is ambiguous. Accordingly, $\frac{\partial \alpha^{*}}{\partial k}$ is negative if and only if $\alpha^{2}>f$, and $\frac{\partial \alpha^{*}}{\partial \mathrm{k}}$ is positive if and only if $\alpha^{2}<f$.

We now turn to testing empirically our principal hypothesis that the relationship between managerial ownership and the bid premiums (abnormal returns) is U-shaped (is inverted U-shaped).

\section{Empirical Tests and Results}

Data Description. We obtained a list of mergers and acquisitions by examining the relevant issues of Mergers and Acquisitions for the years 1985 through 1991. Mergers and Acquisitions lists the name of the acquiring and target firms and the year the merger took place. We then combined these data with the actual date of announcement of the merger, where the announcement date is the date the merger is first mentioned in The Wall Street Journal Index. Subsequently, different issues of The Wall Street Journal that are referenced in the Index are used to ascertain whether the acquisition was a merger or a tender offer, and whether the medium of payment was cash, acquirer stock or a combination of acquirer stock and cash. These data were then combined with daily stock return data. The stock return data for acquiring firms (for the period 1983 through 1992) was obtained from the daily returns file of the Center for Research in Security Prices

\footnotetext{
${ }^{20}$ However, the exact causal relationship is not clear from the empirical studies; our argument is not necessarily the only one supported by their empirical results.
} 
(CRSP). This sample consists of 354 mergers undertaken during the years 1985 through 1991, for which we had complete daily return data and the mergers were announced in The Wall Street Journal.

The managerial ownership data consist of the fraction of stock owned by managers in the year preceding the year of acquisition, and were obtained from the proxy statements filed with the SEC. We also collected the four-digit SIC codes of each line of business in which the firm operates from Dun and Bradstreet's Million Dollar Directory (MDD). MDD lists the six major lines of business of a company, which we gathered in the year preceding the acquisition year. To examine the ownership of large shareholders, we collected information on the fraction of stock owned by shareholders with more than fivepercent ownership in the company. These data were obtained from the proxy statements filed with the SEC in the year preceding the acquisition year. Other financial data, such as the asset size of acquiring and target firms, were obtained from Compustat. We use the value-weighted market portfolio (including dividends) obtained from CRSP as the relevant market index.

Results. We begin our empirical tests by estimating the abnormal returns earned by acquiring firms and test their level of significance using the event-study methodology described in Dodd and Warner (1983). We use an event window of four days before the announcement of the merger to four days after the announcement date $([-4,+4])$.

The return generating process for stock $i$ during time $t$ is given by:

$$
R_{i t}=\alpha_{i}+\beta_{i} R_{m t}+e_{i t}
$$

where $R_{i t}=$ return for stock $i$ at time $t$,

$R_{m t}=$ return on the market (as proxied by the CRSP value-weighted market index) at time $t$,

$\alpha_{i}=$ OLS estimate of the intercept of the market model regression, and

$\beta_{\mathrm{i}}=$ OLS estimate of the slope coefficient of the market model regression.

We estimate the above equation for the 100 days before the event window (namely, $[-104,-5])$, by regressing $R_{i t}$ on $R_{m t}$ and obtaining the OLS estimates $\alpha_{i}$ and $\beta_{i}$. We sum over the prediction errors so as to average out the nonsystematic factors not related to the merger announcement: 


$$
\bar{A}_{t}=1 / N \sum_{i=1}^{N} A_{i t} \text { where } A_{i t}=R_{i t}-\alpha_{i}-\beta_{i} R_{m t} .
$$

The nine-day cumulative abnormal return $C A R[-4,+4]$ for the event window is:

$$
C A R[-4,+4]=\sum_{t=-4}^{+4} \bar{A}_{t} .
$$

The standardized prediction error is given by

$$
S P E_{i t}=A_{i t} / S_{i t}
$$

where $S_{i t}=\left[s_{i}^{2}\left[1+1 / 100+\frac{\left(R_{m t}-\bar{R}_{m t}\right)^{2}}{\sum_{t=-104}^{.5}\left(R_{m t^{-}}-\bar{R}_{m t}\right)^{2}}\right]\right]^{1 / 2}$,

and the residual variance $s_{i}^{2}=1 / 98 \sum_{t=-104}^{-5} A_{i t}^{2}$. The test statistic for the nine-day cumulative return is unit-normal and is:

$$
Z=\bar{W}_{i} \sqrt{N}, \text { where } \bar{W}_{i}=\frac{1}{N} \sum_{i=1}^{N} W_{i} \text { and } W_{i}=\sum_{t=-4}^{+4} S P E_{i t} \frac{1}{3}
$$

The results of the event study is reported in Table 1 . The average nine-day abnormal return is $-0.45 \%$, with an associated $z$-statistic of -2.82 . These results indicate that acquirers experience small but statistically significant decreases in share value upon announcement of a merger. Our results are consistent with the studies described in Jensen and Ruback (1983) and Jarrell, Brickley, and Netter (1988), who find nonpositive abnormal returns for successful acquirers.

We now turn to tests of the relationship between the acquirer's abnormal returns and the level of managerial ownership. Hence, we employ the cross-sectional estimation methodology of Eckbo, Maksimovic, and Williams (1990), while using the nine-day abnormal returns obtained above as our dependent variable. Eckbo, Maksimovic, and Williams (EMW) assume all acquisitions are value-maximizing, whereas our hypothesis assumes that all differences in the bid premiums (and conversely, the abnormal returns) are due to managerial agency costs. Accordingly, we employ the truncated regression technique of EMW, while including only firms that experienced negative abnormal 
returns. The inclusion of firms with agency problems results in a sample of 172 firms. Table 2 presents the sampling distribution for managerial-ownership and large-ownership levels. We find that the mean managerial ownership level is $7.2 \%$ with a large percentage of acquirers (68\% of our sample) having less than five-percent managerial ownership levels. The mean ownership level for large shareholders is $11.9 \%$.

In order to examine the relationship between managerial ownership and the abnormal returns, we construct three dummy variables first used by Mørck, Shleifer, and Vishny (1988). Specifically,

$$
\begin{aligned}
M 1= & \text { managerial ownership level if managerial ownership level }<0.05, \\
= & 0.05 \text { if managerial ownership } \geq 0.05 \\
\text { M2 } & 0 \text { if managerial ownership level }<0.05 \\
= & \text { managerial ownership level minus } 0.05 \text { if } 0.05 \leq \text { managerial ownership level } \\
& <0.25, \\
= & 0.20 \text { if managerial ownership } \geq 0.25 \\
\text { M3 }= & 0 \text { if managerial ownership level }<0.25, \\
= & \text { managerial ownership level minus } 0.25 \text { if managerial ownership } \geq 0.25
\end{aligned}
$$

We estimate three specifications using the truncated regression methodology of EMW (1990), the results of which are given in Table 3. The first specification shows that abnormal returns first increase when managerial ownership levels increase to $5 \%$ and then decrease thereafter. These results are consistent with our prediction. In the next specification, we include the large shareholder variable ( $L A R G E)$ in the spirit of Shleifer and Vishny (1986), who suggest that large shareholders have a greater incentive to monitor managers resulting in a higher firm value. $L A R G E$ is defined as the fraction of stock owned by shareholders with more than five-percent ownership in the company, in the year preceding the acquisition year, and is found to be statistically insignificant. More importantly, including $L A R G E$ does not change the sign or significance of the managerial ownership variables. We also control for differences in the relative size of the acquiring and target firms (see Asquith, Bruner, and Mullins, 1983). We construct the relative size variables $S I Z E$, defined as the logarithm of the ratio of the acquirer's market value of equity to the target's market value of equity. Many of the target firms were missing from Compustat, resulting in a reduced sample of 93 firms. Hence, this third specification has a lower goodness of fit (likelihood function of 311.5) than the first two specifications. We 
find $S I Z E$ to be statistically insignificant with no major effect on the managerial ownership variables. Consequently, the truncated regression results support an increasing and then decreasing relationship between abnormal returns and managerial ownership levels, consistent with the diversification-control hypothesis.

Comparing our results with those of Mørck, Shleifer, and Vishny (1988), we obtain similar findings in the $5 \%$ and $5 \%-25 \%$ managerial ownership range. However, we find that acquirers with higher than $25 \%$ managerial ownership levels earn slightly negative abnormal returns, although this relationship is not statistically significant. MSV find a positive relationship between Tobin's $q$ and managerial ownership for firms with managerial ownership levels greater than 25\%. However, MSV find this relationship to be less significant when managerial ownership levels are below $25 \%$. Consequently, our results are generally similar to the results of MSV; we note two caveats however -- MSV use board ownership levels, while we use managerial ownership levels, and MSV's dependent variable is Tobin's $q$, while we use the nine-day abnormal return of acquiring firms.

An implication of the diversification-control hypothesis described in section 2 is that acquiring firms with high levels of managerial ownership are more likely to indulge in diversifying acquisitions. We investigate for this possibility in Table 4 . We create a dummy variable $S I C$ which takes the value of unity when the acquiring and target firm share a three-digit SIC code. ${ }^{21}$ We split the sample into two sub-samples; the first subsample includes acquiring firms with ownership levels less than $5 \%$, and the second subsample includes acquiring firms with managerial ownership levels greater than $5 \%$. We find that acquiring firms with ownership levels greater than $5 \%$ indeed performed diversifying acquisitions, and this difference is statistically significant at the $10 \%$ level. This result supports the diversification-control hypothesis. In addition, a collateral prediction of the diversification-control hypothesis is that managers with high levels of ownership do not like to lose control and would consequently offer cash as their preferred medium of exchange in a merger. To explore this prediction, we create two dummy variables. The first dummy variable equals unity if the medium of payment is cash, and the second dummy variable equals unity if the medium of payment is stock; both dummy variables equal zero if the medium of payment is a combination of cash and stock. Note that the sub-sample of acquirers with low levels of managerial ownership tend to offer equity (rather than cash) more often than the sub-sample with high managerial ownership levels, although the difference between the two is statistically insignificant. This medium

\footnotetext{
${ }^{21}$ The SIC code for holding companies (6711) is not treated as a separate line of business.
} 
of exchange result does not provide additional support for the diversification-control hypothesis.

\section{Conclusions}

In this paper, we address whether acquirer firms in which managers are significant shareholders behave differently in a merger from acquirer firms in which managers do not own a significant stake. Our model suggests that managers in acquirer firms indulge in non-value-maximizing activities such as perquisite consumption when managerial ownership is low. As the managerial stake increases, the interests of managers become more aligned with shareholder interests. This results in a negative relationship between the bid premium and managerial ownership. However, at sufficiently high levels of managerial ownership, the managers, (who now could be classified as significant shareholders), begin to hold a large nondiversified financial portfolio in the firm. As the managers value control, they are unwilling to sell their stake in financial markets. These benefits of control are increasing in the managerial ownership stake and can lead to managers "overpaying" even when they own a substantial fraction of the firm. Accordingly, managers of acquiring firms overpay when their ownership stake is low (attributable to unobservable perquisite consumption) and when their ownership stake is high (due their private benefits of control). Thus, we hypothesize a negative relationship between the bid premium and the managerial ownership stake at low values of managerial ownership and a positive relationship at high level of managerial ownership. Given that bid premiums and abnormal returns are negatively related, we find strong evidence that the acquirer's abnormal returns first increase and then decrease when their managerial ownership levels increase.

We have implicitly assumed that the financing decision of the acquisition is irrelevant as the firm has sufficient internal funds for the merger. An interesting question is how the issuance of debt or external equity might alter our conclusions. For example, debt limits managerial discretion relative to external equity finance. Does this difference lead firms with a lower managerial ownership stake to use more debt and overpay more? Further, is the risk higher for those firms in which managers have stock option plans? We will address these issues in future research. 
Table 1: Daily abnormal returns earned by acquiring firms. (sample of 354 firms)

\begin{tabular}{|c|c|c|c|c|}
\hline \multirow[b]{2}{*}{ Day } & \multicolumn{4}{|c|}{ Daily Abnormal Returns } \\
\hline & Mean & $\begin{array}{c}t- \\
\text { Statistic } \\
\end{array}$ & Median & $\begin{array}{l}\% \text { of Abnormal } \\
\text { Returns Positive }\end{array}$ \\
\hline $\begin{array}{r}-4 \\
-3 \\
-2 \\
-1 \\
0 \\
+1 \\
+2 \\
+3 \\
+4 \\
\end{array}$ & $\begin{array}{r}0.0016 \\
0.0015 \\
0.0024 \\
-0.0030 \\
-0.0022 \\
-0.0017 \\
-0.0012 \\
-0.0002 \\
-0.0017 \\
\end{array}$ & $\begin{array}{c}1.303 \\
1.323 \\
1.904 \\
-2.635^{*} \\
-3.214^{*} \\
-0.423 \\
0.049 \\
-0.051 \\
-1.072 \\
\end{array}$ & $\begin{array}{r}0.0001 \\
0.0008 \\
0.0001 \\
-0.0020 \\
-0.0021 \\
-0.0022 \\
-0.0010 \\
-0.0008 \\
-0.0018 \\
\end{array}$ & $\begin{array}{l}50.56 \\
53.10 \\
50.56 \\
44.63 \\
44.63 \\
44.35 \\
47.74 \\
47.18 \\
43.79 \\
\end{array}$ \\
\hline \multirow{2}{*}{+4} & \multicolumn{4}{|c|}{ Cumulative Abnormal Returns [CAR] } \\
\hline & \multicolumn{2}{|r|}{ Mean } & $\begin{array}{c}z- \\
\text { Statistic }\end{array}$ & $\begin{array}{l}\% \text { of Abnormal } \\
\text { Returns Positive }\end{array}$ \\
\hline \multicolumn{2}{|c|}{$\begin{array}{l}\text { Cumulative abnormal } \\
\text { returns }[-4,+4]\end{array}$} & -0.0045 & $-2.816^{*}$ & 47.39 \\
\hline
\end{tabular}

\footnotetext{
Statistically significant at the $1 \%$ level.
} 
Table 2: $\quad$ Sample Distribution of Managerial and Large Shareholder Ownership Levels.

\begin{tabular}{|c|c|c|c|}
\hline \multicolumn{2}{|c|}{ Managerial Ownership } & \multicolumn{2}{|c|}{ Large Shareholder Ownership } \\
\hline $\begin{array}{l}\text { Ownership } \\
\text { Levels }\end{array}$ & $\begin{array}{c}\text { Number of } \\
\text { Firms }\end{array}$ & $\begin{array}{c}\text { Ownership } \\
\text { Levels }\end{array}$ & $\begin{array}{c}\text { Number of } \\
\text { Firms }\end{array}$ \\
\hline 0 to $5 \%$ & 117 & 0 to $5 \%$ a & 92 \\
\hline 5 to $10 \%$ & 21 & 5 to $10 \%$ & 21 \\
\hline 10 to $15 \%$ & 10 & 10 to $15 \%$ & 10 \\
\hline $15 \%$ to $20 \%$ & 8 & $15 \%$ to $20 \%$ & 7 \\
\hline $20 \%$ to $25 \%$ & 5 & $20 \%$ to $25 \%$ & 16 \\
\hline $25 \%$ to $30 \%$ & 0 & $25 \%$ to $30 \%$ & 10 \\
\hline $30 \%$ to $35 \%$ & 2 & $30 \%$ to $35 \%$ & 1 \\
\hline $35 \%$ to $40 \%$ & 3 & $35 \%$ to $40 \%$ & 1 \\
\hline $40 \%$ to $45 \%$ & 1 & $40 \%$ to $45 \%$ & 2 \\
\hline $45 \%$ to $50 \%$ & 1 & $45 \%$ to $50 \%$ & 3 \\
\hline $50 \%$ to $55 \%$ & 0 & $50 \%$ to $55 \%$ & 0 \\
\hline $55 \%$ to $60 \%$ & 0 & $55 \%$ to $60 \%$ & 2 \\
\hline $60 \%$ to $65 \%$ & 1 & $60 \%$ to $65 \%$ & 2 \\
\hline $65 \%$ to $80 \%$ & 3 & $65 \%$ to $90 \%$ & 5 \\
\hline
\end{tabular}


Table 3: $\quad$ Truncated Regression Results: Diversification-Control Hypothesis.

\begin{tabular}{|c|c|c|c|}
\hline Variable & (1) & $(2)$ & (3) \\
\hline CONSTANT & $\begin{array}{l}-0.0035 \\
(0.0050)\end{array}$ & $\begin{array}{l}-0.0026 \\
(0.0054)\end{array}$ & $\begin{array}{c}0.0034 \\
(0.0083)\end{array}$ \\
\hline$M 1$ & $\begin{array}{c}0.7786 \\
(0.2920)^{*}\end{array}$ & $\begin{array}{l}0.7659 \\
(0.3031)^{* *}\end{array}$ & $\begin{array}{l}0.3309 \\
(0.1671)^{* *}\end{array}$ \\
\hline$M 2$ & $\begin{array}{l}-0.2170 \\
(0.0866)^{* *}\end{array}$ & $\begin{array}{l}-0.2233 \\
(0.0897)^{* *}\end{array}$ & $\begin{array}{l}-0.1609 \\
(0.0958)^{* * *}\end{array}$ \\
\hline M3 & $\begin{array}{l}-0.0383 \\
(0.0416)\end{array}$ & $\begin{array}{l}-0.0396 \\
(0.0424)\end{array}$ & $\begin{array}{l}-0.0047 \\
(0.0898)\end{array}$ \\
\hline$L A R G E$ & --- & $\begin{array}{c}0.0116 \\
(0.0189)\end{array}$ & $\begin{array}{c}0.0068 \\
(0.0049)\end{array}$ \\
\hline$S I Z E$ & --- & -- & $\begin{array}{c}0.0009 \\
(0.0019)\end{array}$ \\
\hline Number of firms & 172 & 169 & 93 \\
\hline Likelihood function & 573.02 & 565.20 & 311.50 \\
\hline \multicolumn{4}{|c|}{ 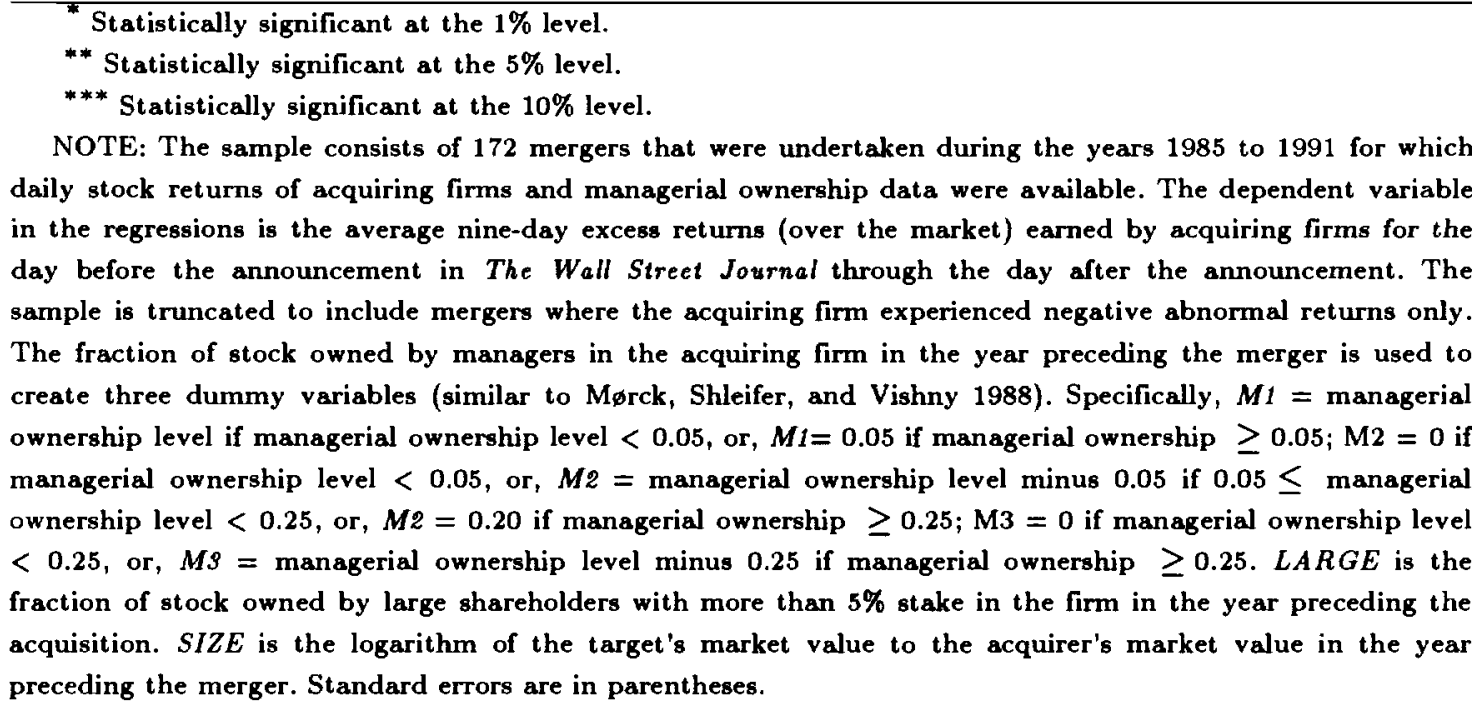 } \\
\hline
\end{tabular}


Table 4: $\quad$ Differences in Low-and-High-Managerial Ownership Firms.

\begin{tabular}{lccc}
\hline & $\begin{array}{l}\text { Sub-sample of } \\
\text { firms with mana- } \\
\text { gerial ownership } \\
\text { levels < } 5 \%\end{array}$ & $\begin{array}{l}\text { Sub-sample of } \\
\text { firms with mana- } \\
\text { gerial ownership } \\
\text { levels }>5 \%\end{array}$ & t-statistic \\
\hline $\begin{array}{l}\text { Variable } \\
\text { a related acquisition }\end{array}$ & 0.596 & 0.500 & $1.68^{*}$ \\
$\begin{array}{l}\text { Dummy for whether the medium of } \\
\text { exchange in the merger was cash only }\end{array}$ & 0.424 & 0.308 & 1.05 \\
$\begin{array}{l}\text { Dummy for whether the medium of } \\
\text { exchange in the merger was stock only }\end{array}$ & 0.389 & 0.346 & 0.38 \\
\hline
\end{tabular}

Statistically significant at the $10 \%$ level. 


\section{References}

AMIHUD, Y., AND LEV, B., "Risk Reduction as a Managerial Motive for Conglomerate Mergers." Bell Journal of Economics, Vol. 12 (1981), pp. 604-617.

ASQUITH, P., BRUNER, R.F., AND MULLINS, D.W., "The Gains to Bidding

Firms From Merger." Journal of Financial Economics, Vol. 11 (1983), pp. 121-139.

BARCLAY, M.J., AND HOLDERNESS, C.G., "Private Benefits from Control of

Public Corporations." Journal of Financial Economics, Vol. 25 (1989), pp. 371-395.

BERLE, A.A., AND MEANS, G.C., "The Modern Corporation and Private

Property." Macmillan, 1932.

DEANGELO, H., AND DEANGELO, L., "Managerial Ownership of Voting Rights:

A Study Of Public Corporations with Dual Classes of Stock." Journal of Financial Economics, Vol. 14 (1985), pp. 33-69.

DODD, P., AND WARNER, J.B., "On Corporate Governance." Journal of Financial Economics, Vol. 11 (1983), pp. 401-438.

ECKBO, B.E., MAKSIMOVIC, V., AND WILliAMS, J., "Consistent Estimation of Cross-Sectional Models in Event Studies." Review of Financial Studies, Vol. 3 (1990), pp. 343-365.

GROSSMAN, S., AND HART, O., "Implicit Contracts, Moral Hazard, and

Unemployment." American Economic Review, Vol. (1981), pp. 301-307.

GROSSMAN, S., AND HART, O., "An Analysis of the Principal-Agent Problem."

Econometrica, Vol. 51 (1983), pp. 7-45.

GROSSMAN, S., AND HART, O., "One Share-One Vote and the Market for Corporate Control." Journal of Financial Economics, Vol. 20 (1988), pp. 175-202.

GROSSMAN, S., AND HART, O., "Corporate Financial Structures and Managerial Incentives." in J. McCall (ed.), The Economics of Information and Uncertainty, Chicago: University of Chicago Press, 1982.

HARRIS, M., AND RAVIV, A., "Corporate Control Contests and Capital Structure." Journal of Financial Economics, Vol. 20 (1988), pp. 55-86.

HERMALIN, B.E., AND WEISBACH, M.S., "The Determinants of Board Composition." RAND Journal of Economics, Vol. 19 (1988), pp. 589-606.

. "The Effects of Board Composition and Direct Incentives on Firm Performance." Financial Management, Winter (1991), pp. 101-112.

HOLMSTROM, B., "Moral Hazard and Observability." Bell Journal of Economics, Vol. 10 (1979), pp. 74-91. 
JARRELL, G.A., BRICKLEY, J.A., AND NETTER, J.M., "The Market for Corporate Control: The Empirical Evidence Since 1980." Journal of Economic Perspectives, Vol. 2 (1988), pp.49-68.

JENSEN, M., "Agency Costs of Free Cash Flow, Corporate Finance and Takeovers." American Economic Review, Vol. 76 (1986), pp. 323-329.

JENSEN, M. AND MECKLING, W., "Theory of the Firm: Managerial Behavior, Agency Costs and Ownership Structure." Journal of Financial Economics, Vol. 3 (1976), pp. 305-360.

JENSEN, M. AND RUBACK, R.S., "The Market for Corporate Control." Journal of Financial Economics, Vol. 11 (1983), pp. 5-50.

LEASE, R., MCCONNELL, J.J., AND MIKKELSON, W., "The Market Value of Control in Publicly Traded Corporations." Journal of Financial Economics, Vol. 11 (1983), pp. 439-472.

LEWELlEN, W.G., LODERER, C., AND ROSENFELD, A., "Merger Decisions and Executive Stock Ownership in Acquiring Firms." Journal of Accounting and Economics, Vol. 7 (1985), pp. 209-231.

MCCONNELL, J.J., AND SERVAES, H., "Additional Evidence on Equity Ownership and Corporate Value." Journal of Financial Economics, Vol. 27 (1990), pp. 595-612.

MØRCK, R., SHLEIFER, A., AND VISHNY, R.W., "Management Ownership and Market Valuation." Journal of Financial Economics, Vol. 20 (1988), pp. 293-315.

OFFICE OF THE CHIEF ECONOMIST, SECURITIES AND EXCHANGE COMMISSION, "The Effects of Dual-class Recapitalizations on the Wealth of Shareholders." 1987a.

SAUNDERS, A., STROCK, E.S., AND TRAVLOS, N., "Ownership Structure, Deregulation and Bank Risk Taking." Journal of Finance, Vol. 45 (1990), pp. 643-654. SHLEIFER, A., AND VISHNY, R.W., "Value Maximization and the Acquisition Process." Journal of Economic Perspectives, Vol. 2 (1988), pp. 7-20.

- "Large Shareholders and Corporate Control." Journal of Political Economy, Vol. (1986), pp. 461-488.

STULZ, R.M., "Managerial Control of Voting Rights; Financing Policies and the Market for Corporate Control." Journal of Financial Economics, Vol. 20 (1988), pp. $25-54$.

WILSON, R., "The Theory of Syndicates." Econometrica, Vol. 36 (1968), pp. 119132. 